Војо Ковачевић

Универзитет у Источном Сарајеву

Филозофски факултет Пале

Катедра за српски језик и књижевност

https://doi.org/10.18485/ai_zsjoski.2019.2.ch8

821.163.41.09-1 Радичевић Б.

811.163 .41

\title{
ВУК И БРАНКО
}

Збирка песма Бранка Радичевића Песме, публикована 1847 године, означава незваничну победу Вукових идеја утемељених на прихватању народног језика и фонетског правописа као нормираног или стандардног језичког израза. Тријумфу Вуковог верује допринела су, такође, и три друга дела објављена исте године - Горски вијенаи Петра Петровића Његоша, Рай за срйски језик и йравойис Ђуре Даничића и превод Нової завјей $а$ Вука Ст. Караџића. Уметнички квалитети Бранкових песама необорив су аргумент у исправност Вуковог учења и најснажнија критика „певања и мишљења” његових противника. У овом раду научнокритички ћемо анализирати уметничке квалитете Бранкових лирских песама, почев од фонетских и морфолошких до лексичких и синтаксичких особености српског народног језика. Укрштањем књижевноисторијских поступака са методолошким учењима структура-

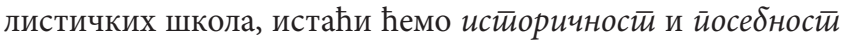
Бранковог песничког израза, сагледати његове стилске ознаке и књижевноуметничке домете.

Къучне речи: Бранко Радичевић. поезија, народни језик, Вук Ст. Караџић, реформа, традиција, уметност.

Немерљив је допринос Бранка Радичевића победи Вукових идеја, примарно у погледу конституисања 
народног језика као стандардног или нормираног израза. Његова књига Песама публикована 1847. године крунска је

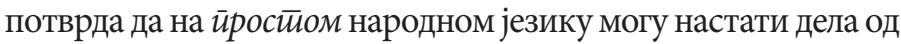
највеће уметничке вредности. Са становишта језика и стила, мелодије и ритма, песничке фактуре и садржаја, песништво родоначелника српског романтизма представља прекретницу у развоју српске лирике. Проводећи књижевнокрититичку анализу о особеностима његовог песништва, J. Деретић (2002: 716) констатује: „Бранко је велики почетак наше поезије, почетак једног основног, лирског тока у новој књижевности, али није почетак у једном већ у више праваца".

Иако доследно прихвата идеје Вука Ст. Караџића, уметнички квалитети његове поезије се не ограничавају само на употребу новог правописа и народног / говорног језика, већ засецају и у многе националне и културолошке проблеме. Свој став о српским литерарним, језичким, институционалним и културолошким приликама, грешкама и заблудама, најексплицитније је изнео у сатиричном спеву Пуй, где, у развијеним алегоријским сликама, колоритно осликава прилике у српском друштву, политици и култури. Посебно апострофира њене „дичне” синове, „прекомерно” учене Матичаре и конзервативне листове, Драїољуба и Авалу, чија деловања изједначава са мрском турском управом, са једне стране, док народна гласила иронично пореди са упарложеном „њивом”, где се „цветови” расцветавају у шикару и коров: „Амо, куйуј народни новина, / Све шеница gа йе је милина, / Драїолуба и яруїи иветиова, / И селена народни листиова!" / А ја вияе како навалице / Коси кукол, чуйа йра-

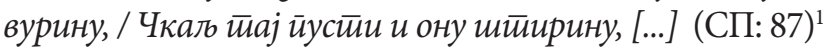

Бранко Радичевић, дакле, остварује радикалан прекид са дотадашњом писаном поезијом, уводи чист

1 Стихове Бранка Радичевића наводимо према издању Сабране иесме, приредио Душан Иванић, СКЗ, 1999, а означаваћемо скраћено - СП. 
народни језик, са израженим обележјима дијалекатског, открива његове не само литерарне, већ и сазнајне вредности и изражајне могућности. Језик усменог народног стваралаштва у његовим песмама садржи особиту новину, поглавито на нивоу живог представљања спољашњег света, али и унутрашњих стања лирских субјеката. За разлику од песника норматиизоване класицистичке школе и песника „хладних чувстава” која су неговали песници тридесетих година XIX века, поборници школе тзв. „објективне лирике”, Радичевић успева да разобручи језички израз, учини га гипкијим, ослободи машту, и, посредством језика и препознатљивих језичких конструкција, продуби мисаоно-емотивне садржаје, психолошка стања и унутрашње доживљаје. Сличне поетске квалитете препознајемо и у нашим народним песмама, али Бранкове лирске песме садрже и видно наглашене индивидуалне црте и раскошне језичке варијације, особито пластично сенчену метафоричност, која се везује за појаве из природе, са наглашеним личним експресијама. У складу са романтичарским „верује”, он успева да поврати поверење у реч, тим пре, што настала криза у писаној књижевности, али и у расцепканом српском друштву, нужно изазива и неповерење у језик и реч. Романтичном заносу страни су сувопарни и извештачени облици црквенословенског и рускословенског језика, као и „сладуњавост” славјаносербског. Разметљивост сувом и бесплодном наобразбом - музама, античким боговима и јунацима, библијским митовима и легендама - Радичевић поима као опсену или бег од туробне стварности, мрену што магли поглед и мути мисли, пречи развитак народности, просвјете и друштва:

[...]

Ваљда мед се по земљици лије, Јер кошница не мож’ га да сакрије. 
Скочи брже с Пегаза лакога, Довати се уљаника тога, Па у једну кошницу загледа, Кад ал' у њој ни трага од меда, [...]

Нигде меда ни најмање мрве!

Шта је ово, зар се тако ради?

Гледну челе, ох дивне чељади,

Та све они красни соколови,

Све трутови, да Бог благослови!

(СП: 86-87)

Нескривено карикирање и травестирање српских првака и друштвеног амбијента, прати ироничан тон помешан са саркастичним опаскама. И то је главни узрок што се од Пуй а оградила српска Омлаgина, којој је песник посветио свој песнички првенац: „Аутор те ограде, Светозар Милетић, Хаџићев питомац, духовни вођа војвођанских школараца у Пожуну (Братислави), а доцније и српског народа у Војводини, није могао отрпјети грубо исмијавање свога добротвора ни појачавање раздора међу књижевним супарницима. [...] осјетио је како Бранкове пјесме умјетнички надмоћно игноришу све оно што су пожунски омладинци уграђивали у своје пјесничке творевине - моралност (нравственост), образованост, науку, панславистичке идеје или чак идеје народне слоге (Иванић 1999: XIV-XIV).

Генеза и природа језичке диглосије која је у развоју српске књижевности, културе и писмености премашила цео један век, била је добро позната не само Вуку и Бранку, већ безмало и свим друштвено-политичким и културним прегаоцима и ствараоцима тога доба. Познати су, такође, неслагања и чегрсти око питања која засецају у области филолошких и књижевних садржаја, а које су заступали писци, црквени великодостојници 
и културно-политички делатници. Релевантно је, свакако, мишљење Доситеја Обрадовића које, у најкраћем облику сумирано и у нужној мери уопштено због карактера нашег рада, експлицитно исказано у Писму Хараламйuју и касније проведено у његовим другим делима, подразумева нужно прихватање народног језика, али и задржавање речи црковенословенског или рускословенског језика за појмове везане за области развијеног и рафинираног духа, нпр. науку, филозофију или теологију, односно уз апстрактне појмове, са образложењем да прост народни језик нема адкватне изразе који означавају назначене стваралачке процесе и њихове језичке ознаке. Други значајан став о назначеном проблему износи најӣошӣованији и најїлавнији српски писац, Лукијан Мушицки, препоручив компромисно решење: Славенскиј и сербскиј језик - gва су йуйа! / К јеgној иели воgе нас (2003: 609). Оба аутора деле мишљење да се задржи црвенословенска или „славјанска” лексика за именовање појмова или феномена из области филозофије, теологије и других научних дисциплина. Увиђају, такође, сагласно Хердеровом мишљењу и холистичком учењу, да језик најверније одражава дух народа. У Гласу „генија српског рода”, како је Његош називао Мушицког, експлицитно се наводи: Наша с наречја, gа Сербе; / Ал' им іранииу тии gај. За красне мисли узми красне ризе / Крој gај ризама gвојака (2003: 609).

Имајући у виду чињеницу да је српски народ већ првих година XIX века отпочео одсудну битку за национално осамостаљење и уједињење, а та битка се била не само оружјем, већ и књигом, образовањем и културом, његову прву књигу песама можемо непосредно довести у тај друштвеноисторијски и културолошки контекст. Имајући у виду шири историјски оквир, песник опомиње на косовско вековно судилиште: Ноћ нам gође са Вука јеg-

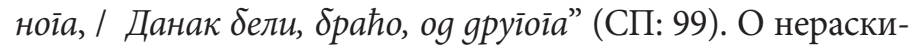


дивим и узајамним везама природе и функције језика и мишљења са судбином народа, поучна су размишљања Октавијана Паза (1979: 37): „Историја човекова могла би се свести на историју односа мисли и језика. Сваки период кризе почиње критиком језика". И Вук у свом дуготрајном и доследном реформском раду као да је имао на уму сличне ставове, а беспоштедно противљење увођењу новог језичког израза, великим делом је условљено и чувањем личних, институционалних или класних разлика, односно привилегија стечених на до тада утврђеним вредностима. Зато не чуди што се у полемикама везаним за назначена питања, њени актери не либе да своје опоненте дискредитују, не само на разини научне компетентности, већ и грубим задирањем у сфере посве личног карактера. Свестан тежине свог рада и потенцијалних приговарања, Вук је деловао правовременим и жустрим одговорима, убедљивом критиком и чврстом аргументацијом, али и прикупљањем и објављивањем ванредних дела усменог стваралаштва. Презентацијом вековима брушеног народног стваралаштва, Вук упознаје европске народе са историјом свога народа и карактером његовог духа, скреће позорност на њихову стваралачку снагу, рафинман осећања и мишљења. Следи модел развијенијих националних заједница уједињених на принципима заједничког језика, вере и традиције: „Када су европске нације стварале језик, легенде и песме, допринеле су стварању самих тих нација. У једном дубљем смислу, оне су их засновале: дале су им свест о себи самима" (Паз 1979: 47). И Андрић (1981: 124) дели исто мишљење: „[...] језик је, то сви знамо, жива снага са којом је везана не само култура него и само постојање једног народа".

Стварајући своје литерарно дело, један од најзначајних српских савремених писаца и поборник Вуковог „певања и мишљења”, најузорнији стилиста српског језика, осврнув се на оновремене друштвене и културолошке прилике, закључује: „, [...] Вук је својом упорном и непоколебљивом 
борбом тукао противнике до потпуног уништења, а својим дугим животом чак их и физички надживео. И на крају, све што је остало, људи и установе, изгубило се у општем признавању Вуковог дела и једногласном слављењу његове личности. (Ревност коју су у том сви показивали могла се, по свом интезитету, упоредити само са оштрином са којом су га гонили за првих тридесет година његовог деловања.)” (Андрић 1981: 93).

Дакле, бурна историјска и политичка збивања у којима је Вук и непосредно суделовао и најнепосредније подупирао разноврсне националне програме, пре свих оне који се тичу језика и књижевности, образовања и културе. Прворазредан значај као и далекосежност проблема тог карактера једнако су били живи и у најдревнијим временима. У XIII књизи Анала, Цу Лу пита Конфучија: 'Кад би те војвода од Веја позвао да управљаш његовом земљом, коју би меру прво предузео?” Маестров одговор је гласио: 'Реформу језика' (37-38).

Због сложености природе језика и његових рефлексија не само у сфере духа, већ и разнородне сегменте друштва, Вукова реформа „ [...] означава стално живи интерес за питања језика и културе, а истовремено открива веома различита, често и сасвим супротна становишта који имају општекултурне али и класнодруштвене изворе, данас мање уочљиве и мање важне него раније. Разлози прихватања или одбијања вуковског, народског, у основи сељачког језика различити су у разним временским раздобљима: у првим деценијама века то је део борбе за стварање нације и слободне српске државе; у време Недићево, а поготову Скерлићево, почеци европеизације и интензивније урбанизације Србије покренули су процес грађанске еманципације и у овој сфери; у наше време, акумулирана духовна и културна искуства као и неопходност достизања европског па и светског нивоа, захтевају богатији, разуђенији, еластичнији језик, способан да изражава сложену 
свеукупност живота и света [...] тако је спор око језика оживљавао увек у прекретним временима, кад се нешто битно мењало у нашем друштвеном животу", напомиње Меша Селимовић (1990: 5-6). Дакле, језичка реформа коју је Вук отпочео изазивала је реакције, са већим или мањим интензитетом, и у наредним столећима. ${ }^{2}$

Бранкова прва књига Песама посведочује његов

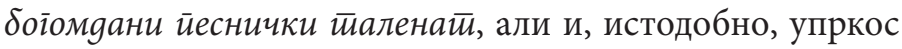
тој чињеници, изазива бурну реакцију у оновременој књижевној критици, култури и друштву. Критика је изабрала две тачке за своје приговоре: иронично-сатиричан тон и груба критика, као што смо навели, норматизоване литературе и њених аутора изражени у спеву Пу $\bar{u}$, с једне стране, затим, употреба дијалектизама и локализама, а посебно вуліарних израза, те мноштво огрешења о граматички систем, с друге стране. Ови приговори, на први поглед, изгледају основани, а, како су исказани од многих образованих људи тог времена, Бранкове песме су се доживљавале као својеврсна језичка играрија, обесно слободна и мисаоно бледа. А и сам песник је био свестан посебности свога израза, емотивних и мисаоно-идејних садржаја, наглашене младалачке узнесености, веселости и разузданости. То потврђују његови стихови упућени Петру Петровићу Његошу, сачињени неколико месеци након штампања збирке Песама, јануара 1848. године:

2 Селимовићев суд исказан је почетком седамдесетих година $\mathrm{XX}$ века, две деценије пре него што су поновно актуелизована питања везана за природу Вуковог језика, а чији су корени примарно политичког карактера. Варијанте српског језика постале су, упркос научно утемељених лингвистичких критеријума, изговор за ненаучно конституисање хрватског, босанског и црногорског језика. 
Ој владико, Црној Гори главо, $[\ldots]$

Ево тебе једне књиге беле, Чеда мила моје крвце вреле, На весеље свако је попашно, А душа му и ноћу и дању

Сваку празну разбити лубању.

Ox, опрости, ако с права пута Кадикада млађано залута.

[...]

Боље чедо и пређаволасто, Нег богаљче и слепо и кљасто, Да уз туђи корак нарамује, Да га туђа рука зарањује!

(СП: 209)

Бранково поједностављено описивање садржаја и карактера властитих песама, уз јасно изражен лични став, заоденут у рухо йросӣо $\bar{\imath}$ народног израза, како у погледу лексике, тако и у погледу мелодије и ритма, неосетним померањем основног значења, метафорички сугерише своје главне идеје, разоткрива властито „певање и мишљење”, посебно истичући топос слобоgе, не само у стваралаштву, већ и у природном развоју појединца и народа.

Бранко, дакле, у већини песма значењску основу и језички облик везује за свакидашње појаве, стварносне односе и природни амбијент, благо их поетизује и семантички усложњава. Та врста померања на морфолошкој, лексичкој и синтаксичкој равни, представља својеврсну песничку технику коју Бранко штедро користи и усавршава. Уметнички инвентивно обликује, слободно можемо рећи, уху и духу одвећ познате садржаје, чије је Извориште у српском усменог стваралаштву. Ослањајући се каткад на скромне или, пак, крње пословичне изразе, активира разнородна семантичка поља. Илустративан 
су пример придеви и поређења која користи е да би песничке слике одражавале најпропрозрачнију лепоту и задобиле колоритну сугестивност: живо gетее, чеgа мила,

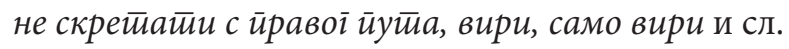

У Бранковим песмама природа (са)учествује у наслађивању разноврсним играријама које настају као манифестације чистих емотивних стања - (О томе види више: (Ковачевић 2018: 211-218)
[...]
Ал' и мома из засеgе
Поскочила ома -
Бежи, селе - етио беgе -
Бежи мајии дома!
[...]
О gа чудна љьуғушкаға, Да й' йоgиђу мрави!

Лаки ветирић осмену се, Листиак лиска gирну, Бели данак ӣокрену се

Па кроз тиӣу вирну.

(СП: 23)

Живо предочена експресивна сједињења помамно натапају песничке слике, остварује се нераскидива веза природе са нежним трептајима и узаврелим немирима душе. Колоритне сугестије зорно одржавају унутрашња стања песничких субјеката, њихових искрених тежњи усмерених на доживљавања сваковрсних лепота. Природа у коју нас уводи Бранко покривена је палетом чистих и свежих боја. Ни трага ружнима. И бол, којом бивају каткад натопљени његови стихови, никада није горка нити жалосна, док подсећања на минуле љубавне јаде једнако доприносе стишавања боли. И та бол остаје 
лепа од љубави, а дискретна сенчења тамних осећања, којима се оцртавају ритмички усеци, стапају се са императивним зазивањем смрти, као у песми Јagнa gраїа. Интензитет боли комплементаран је степену и карактеру љубавних осећања:

[...]

Ја сам млада

Овде сада

Ко и пре

Сунце бега,

Ал' нема њега

Као пре

Нема сунца миленог

Нема мог.

[...]

Ој вечери, о слатко чекање,

О ви, ноћи, моји бели дани,

О ви, дани, а са два сунашца,

Де сте јако, де је злато моје?

Плачи, траво, запевај, славују,

Злато моје земљица покрива!

Мили Боже подигни олују,

Сред ме срца громом удри жива!

Рака њега крије сад и тама,

Шта ћу овде ја на свету сама!

(СП: 35)

Избор речи и њихове фонолошке вредноте, алитерациона и асонантна преплитања као и раскошна фонетска организација, потом функционална мотивска повезивања, остављају утисак познатог, присног и неусиљеног певања. Одвећ знани и у свакидашњем говори често коришћени мотиви: іллава, књиіа, чеgо, рука, корак, 
усне, йољуйии - имају потребну и довољну моћ да најнепосредније опомену на значај слободног развој као предуслова за ванредна постигнућа, а топоси у песмама љубавног карактера: усне, йолуйци, веселе, сунце, вечер, - дочаравају оживљену природу и млада бића љубављу опијена. Те песме су својеврсна химна животу.

Присност и поверење који карактеришу прву књигу, огледају се, дакле, у томе што су мотиви које уносе и повезују унутар песме од искона знани, познати и стари колико и свет. Природност сунца и месеца, извора и реке, шуме и поља, потом младића и девојака, израз су афирмације слободног живота у крилу природе што се испољава у љубави и игри, забави и весељу. Маркацијом топоса из природе - суние, сунчеви зраци, месеи, река, $\bar{u} о \bar{u} о \kappa, ~ ш у м а, ~(\bar{u}) \bar{u} и ц е$ - уобичајених природних појава и животних радњи, свакидашњих догађања пропраћених слободним конвенционалним ословљавањима и фразелошким изразима, у Бранковим песмама попримају сугестивне рефлексије које откривају сложена емотивно-чулна стања и психолошке одблеске. ${ }^{3}$ Песник успоставља живу везу између стања душе и описа природе или природног амбијента, уз успостављања интерактивних комуникативних веза са наглашеним колоквијал-

3 На почетку свога певања и Ј. Јовановић Змај и Ђура Јакшић, угледали су се на Бранкове лирске песме, подражавали су сличне тематско-мотивске профиле и творили песничке слике чији детаљи, мотивски маркирани пунозначним речима именицама, придевима или глаголима - попримају метафоричко значење, означавајући емотивна стања лирских субјеката. Илустративан пример је кратка лирска песма осенчена сетом Ђ. Јакшића: „Боловаћу и умрећу, / Рани биља наћи нећу; / Рани мојој нема тека, / Докле итраје земної века. / Драїа ј' мени рану gала, / Небу каg ме іоре звала. / Она оgе, а ја остиа', / Болно срие оняа йостиа. / Али gаће, gаће рака / Смритној мојој рани лек,” стихови: „Каg би мома звезgа била: - никаg не би gуша моја / Бела gанка зажелила.-" 
ним цртама: „gajge, селе, мало воgе!” / Ове речи - слайке сииреле - минуше ми іруgи беле [...]” (СП: 7) . Човекова унутрашња стања, мисли и осећања, именују се у складу са чистом природом и неисквареним језичким изразом, а његове стваралачке снаге испољавају се у љубави, игри, риболову, забави и песми.

У Радичевићевим лирским песмама живо су представљене чисте емоције или унутрашње експресије, лишене сваке врсте скрупулозности, јер искреној и бурној емотивности, рацио постаје реметилачки фактор. Стога песник твори лирске субјекте што целим својим бићем жуде да се стопе, који слуте душе подобне властитој, а оживљавају их и развијају у машти и сну. Потреба да се биће дели са другим, затим рефлексије о превладавању властите ограничености и усамљености, представља један од основних топоса романтизма. Непосредним истицањем интуитивне способности да се људско биће стави у положај другога, или да се друга особа скоро у целости доживи као властита, остварује се имагинативним транспоновањем објективне стварности у сферу идеалног. Романтичари посебно апострофирају идеал апсолута / апсолутног, како у трагању за таквом љубављу, тако и у погледу уметничког стварања. На тој равни се измирују и нераскидиво сједињују чулни надражаји са рефлексијама духа, а у стваралачком процесу унутрашњи пориви се превладавају тек у уметничком делу. Досезање апсолутног јединства остварењем идеалне љубави, потпуним сједињењем драгог и драге, или, пак, трагањем за апсолутним изразом, израз је нераскидивог, органског јединства чулних опажаја са духом. Појам апсолутног подразумева сједињење где никакво делење не може да се изведе, а да се при томе не преиначи суштина онога што треба да буде дељено, јер се „апсолутно јединство једино остварује интелектуалним интуирањем” (Кроче 1991: 14) у уметничком делу. 
Песници у трагању за апсолутним изразом истодобно трагају и за својим бићем и његовим јестетством. Хегел закључује: „Дух је способан да посматра сама себе, то јест да је способан да има свест, и то такву свест која је у стању да мисли о себи и свему што из духа пониче. [...] Уметност пак и њена дела, као дела која су поникла и постала из духа, јесу и сама по својој природи духовна, премда њихово излагање прима у се привид чулности и оно што је чулно прожима духом" (1976: 114). У сталном трагању за властитим сопством, Новалис императивно захтева и пророчки суди: „Јаче се учврстити у непролазном, божанском у нама”, што рани романтичари следе и песнички обликују.

Сведоџбу о комплексности стваралачког процеса чине безбројне редакције уметничких текстова, некада познатих, а најчешће неповратно изгубљених. ${ }^{4}$ У Радиче-

4 Види: Бранко Радичевић, Сабране йесме: приредио Душан Иванић, СКЗ, Београд, 1999; Приређивач бележи сваку измену у различитим редакцијама песама како на нивоу правописа и нормативне граматике тако и у погледу песникових измена на нивоу фактуре, стила и језика песничких дела. На основу многобројних промена, препознаје се ванредан песнички дар, мелодијско-ритмички осећај, богата ерудиција те познавање духа народног језика, културолошког амбијента и емотивно-психолошких стања лирских јунака. Илустративан пример су редакције рефлексивне песме Kag млияија умретии и поеме Ђачки растианак; Песма Kag млияија умреиии штампана је први пут у Даници 1861 , а потом у постхумној збирци 1862. године, коју је приредио Бранков отац Теодор Радичевић. Песник је прву верзију песме, опширнију и разуђенију, написану на пет страна и најавио за прву збирку1847. Измене које је касније вршио примарно се односе на форму, мотиве, песничке слике и, свакако, лексику. Строфичне и лексичке измене доприносе не само снажнијој експресији и сложенијем мисаоно-идејном пољу, већ и рафиниранијим и естетизованијим квалитетима: „Глава клону, лице йойавнило, / Боловане образе йоиило, / Око [...] иеело йоломтено,/ А клеча ми слабачко колено: / Дође gоба gа ияем у іроба (СП: 741). Боже (Боже) / Зар ме јача стиворитии не може? [...]" Истакли смо само део стихова, а целу песму види у: (СП: 550-554). 
вићевој љубавној лирици, у сфери љубавних доживљаја, праћених пластично дочараном маштом, која је богаћена мноштвом мотива који оцртавају поетизовану амплитуду пожуде и страсти. Многострукост песникове уобразиље, подстичу „закони” срца, а ти „закони” су противни удворничким и калкулаторским, „норматизованим” мислима. Ту супротност песник дочарава увођењем опозитних мотива, чија семантика покрива емотивне и мисаоне садржаје, јер потискивање или потирање мисли, сугеришу чисте емоције. А младалачка снага тих осећања, подстрекава дух који се слободан издиже изнад свих правила и забрана. У Бранковим лирским песмама, као што смо навели, на нивоу лексике или песничких слика, мелодије и ритма, уочавамо унутрашњу разиграност лирског субјекта и љупкост произведених

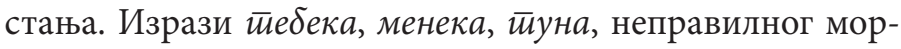
фолошког облика, својеврсна су сведоџба о излишности језика / говора у и тим тренуцима и таквим емотивним ситуацијама: Ал' и мома из засеgе / Поскочила ома - Бежи, селе - ейо беgе - / Бежи мајии gома! (СП: 23)

Нестандардним продужавањем лексичких облика и творбом поетизованих лексема, настоје се ублажити узаврела страст осенчена детаљима љубавне игре, праћене језичким креацијама и равномерним ритмичким понављањима. Дионизијско разгласавање лирског јунака и братски, буколички одзив природе, израз су афирмације младости, љубави и живота: Лаки ветирић осмену се, / Листиак тиска gирну / Бели данак йокрену се / Па кроз іору вирну (СП: 23) - суптилни трептаји природе сугеришу дах етеричне сензуалности. Жив и непосредан однос лирских субјеката и природни амбијент се стапају. Фиктивни дијалог премрежен је елизијама у изразу: заи$\bar{u} и л а, \bar{u} и о, ~ о м а, ~ и \overline{и н у о, ~ о с м е и в а, ~ а ~ и з о с т а в љ а њ е м ~ г л а с а ~ х, ~}$ чије је порекло страно и мелодијско-акустичка својства врло затоворена и опорија, постиже се бржи ритам, суге- 
рише младалачки занос и неспутану игру саображену дионизијском расположењу.

Бранко Радичевић често користи изразе чуgно / чуgна чија се стилогеност заснива на семантичком нијансирању лепоте, љупке и прозрачне. Романтичарска поезија са својим смислом за тајанствено и чудновато поприма својства мистичног и фантастичног. А Август В. Шлегел у том смислу препознаје и обележја „непосредно религиозна", 5 као изразе снажних подстицаја асоцијативних и имагинативних поља, којима се додатно усложњава осећајност и сензуалност. Јер „искључивањем” менталних, разумских одређења, оставља се безграничан йросииор за оспољавање осетилних.

Песничка ивентивност и креативност огледа се и компоновању дела, његовој фактури и обиму, који сугеришу специфична духовна озрачења, мисаоно-емотивна и психолошка стања. Искључивањем менталних процеса, сугеришу се потенцијална оспољавања чулних угођаја, а потирање сирове страсти и анималистичких порива, остварује се зрачењима духовних садржаја. Тако предочена осетилна стања садрже естетски квалитет утемељен на опреци духовно / натуралистичко, односно лепо / ружно.

Мотивска уланчавања као рефлексије младалачких зазивања остављају привид слободних играрија. Семантичке вредности топоса клейве, утврђене у епском памћењу, садрже „обавезујућа” етичка начела - 'Ко је Србин и срйскоїа роgа / [...] а не gошо на бој на Косово / не имао оg срияа йороgа [...] Рђом кайо gок му је колена' (Вук II, 46) - насупрот тим строгим мерилима - у Бранковој лирској песми Клешива, маркирани топос сугерише афирмацију љубавнних чаролија и животних радости:

5 Према: Ридигер Зафрански, Романӣизам: јеgна немачка афера, превела са немачког Мирјана Аврамовић, Адреса, Нови Сад, 2011, стр. 111 
Зелена је трава,

Мома на њој спава,

Вијар ветар пирну,

У сукњу јој дирну.

Сукњица се шири

А ножица вири.

Ао ноно бела,

Вода те однела

Па - мени донела!

(СП: 44)

Са естетичког становишта садржаји назначених стихова, те њихова колоритност, стварају привид игре као битне чињенице естетске делатности. Јер појам игре је понекад помагао спознаји активистичког карактера естетичке чињенице. „Човјек (тако се говорило) није доиста човјек док се не почне играти (то јест кад се издвоји из природне и механичке каузалности, производећи духовно), а прва је његова игра умјетност. Но, будући да ријеч 'игра' значи и угоду која произлази из изазваног пражњења енергије што навире из организма (то јест из практичне потребе), као посљедица те теорије свака је игра названа естетичком чињеницом, или је пак умјетност названа игром, утолико што дјеломично може бити укључена у игру, као што се догађа и код других ствари, чак и код знаности. Само моралношћу никад не може владати (због протурјечности која ту допушта) жеља за игром, јер она влада и управља самим чином игре" (Кроче 1991: 87 - 88)

Радичевић је дубоко свестан феномена језика, његових изражајних могућности, али, истовремено и његове недостатности да нераскидиво сједини разнолике унутрашње експресије укотвљене у безграничном духу. Песничко приказање „света” је у нераскидивом односу са звуком и значењем којима се твори дело. Према Ингар- 
деновом мишљењу „значење речи, ношено неким гласом, узето само за себе је затворена јединица смисла која интендира одређену предметност; mutatis, mutandis, речи здружене у (исказну) реченицу интендирају, вршећи своју вербално - номиналну функцију развијања одређеног стања ствари, помоћу специфичне реченичне интенционалности, такозвани реченични корелат;" (Стојановић 2011: 43-44) Стога песник прибегава изналажењу првотних језичких облика, творећи одговарајући језички сасуд, у којем се оспољавају таква стања:

„Свирац свира,

не да мира,

А још више девојчице,

Њине очи и ножице,

Деде, брате, ију јуј!

Де поскочи, не лудуј,

Ко би јако момак био

Па се не би помамио!

Ао селе босонога,

Зла ти мајка дозлабога,

Не дала ти чарапица

Ни лагани папучица,

Да учиниш клепа - клапа -

За тобоме, душо, скапа.

Охо, селе, вита стаса,

Држ’ се браци око паса,

Коловођа колом вија,

Који лети, зној пробија,

Ал' у твоји недри туде

Окле снега до две груде?

Чудо, селе, дивно чудо,

Ала би се млађан грудо!"

(СП: 62) 
Радичевићев језик је вуковски сведен, чист и једар. Семантика многих дијалекатских израза и њихових морфолошких облика, примарно се односе на источнохерцеговачке говоре, уз знатан број локализама и провинцијализама. Њихови квалитети су изразито поетски, утемељени, као што смо навели, на свим нивоима језика, почев од фонолошког до синтаксичког. Алитерациони и асонантни низови, уз честе елизије, сенче не само емотивно-психолошка стања, већ и менталне и духовне садржаје лирских јунака. Песник врло често користи деминутиве или хипокористике, изразе чије стилогене вредности неретко сугеришу извештачена и сладуњава осећања, али у структури Бранкових песама њихова сематика садржи рафинирану духовност и прозрачна

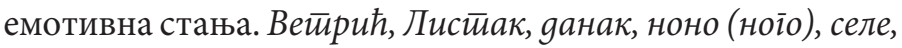

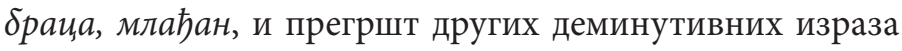
утканих у структуру његових песама, остављају утисак нежног расположења, етеричних стања и доживљаја.

Иако је, дакле, употреба народног језика у српској литерарној традицији присутна и много пре појаве Бранка, тек са Бранковим Песмама долазе до изражаја његова гипкост, мелодичност, семантичка и граматичка сложеност, како у односу на говорне специфичности, тако и у односу на дотадашњу усмену и писану књижевну традицију. Темељни значај његове поезије јесте уметнички допринос у утврђивања граматичког система на народном језику. Сложени односи које је развио у својим песмама на нивоу мисли и осећања, маштовитости и инвентивности, ритмичности и мелодичности, као и квалитете на језичким нивоима, почев од фонетског до синтаксичког, свакако су највећи допринос победи Вукових идеја. Јер, граматички систем нам пружа, али истодобно и намеће извесну мрежу односа, у чијим оквирима можемо и морамо изразити наше сазнање, а у структури песничког / књижевног текста, најнепосредније се очи- 
тује специфично експонирање граматичких категорија. Поред те чињенице, у Бранковим песамама је изражено и нарушаване граматичког система у исказу као поетолошки, стилогени и полисемичани елементи метајезика, а њихове вредности долазе до изражаја подједнако и на синхроној и дијахроној равни.

Прихватањем Вукове реформе и стварањем поезије на народном језику, као и у духу лирских народних творевина, Бранко Радичевић је свакако сачинио ванредно песничко дело, пресудно је утицао на даљи развој српског лирског песништва. Његова поезија садржи обележја романтизма, поглавито немачке романтике, и српског народног песништва. Сугестивним и живим језичким изразом песник тематизује љубавна осећања, родољубље, историју и традицију, као и национално освешћење. Радичевић је један од ретких песника који је већ првом књигом Песама 1847, иако грубо оцењеном од стране „званичне” критике, постао узор и многим каснијим генерацијама песника, а његово песништво остаје узорно мерило уметничких квалитета, инвентивности, језичке гипкости и сензибилности.

\section{Литература}

Андрић 1981: Иво Андрић, Вук, реформатор, у: Умейник и юеі̄ово gело, Сабрана дела, књ. 13, Удружени издавачи: Просвета, Београд; Младост, Загреб; Свјетлост, Сарајево; Државна заложба Словеније, Љубљана; Мисла, Скопје; Побједа, Титоград.

Андрић 1981: Иво Андрић, Оптимизам Вука Караџића, у: Уметиник и юеіоово gело, Сабрана дела, књ. 13, Удружени издавачи: Просвета, Београд; Младост, Загреб; Свјетлост, Сарајево; Државна заложба Словеније, Љубљана; Мисла, Скопје; Побједа, Титоград. 
Зафрански 2011: Ридигер Зафрански, Романииизам: јеgна немачка афера, превела са немачког Мирјана Аврамовић, Нови Сад: Адреса.

Деретић 2002: Јован Деретић, Исӣорија срӣске књижевностии, Просвета, Београд.

Иванић 1999: Душан Иванић, Пјесничко gјело Бранка Раguчевића, у предговор: Радичевић, Београд: СКЗ, Сабране песме. Ковачевић 2018: Војо Ковачевић, Лирске песме Бранка Радичевића, Зборник радова са 10. међународне интердисциплинарне научно-стручне конференције „Хоризонти” 2018: ИКТ у васиичйаюу и образоваюу, сиориту и меgииини, 211218, Суботица.

Кроче 1991: Benedetto Croce, Estetika kao znanost izraza i opća lingvistika: teorija i historija, prevod s talijanskog Sonja Roić, Zagreb: Globus.

Мушицки 2003: Лукијан Мушицки, Глас народољубца - песма лирическо-дидактическа посвећена сербском роду, у:

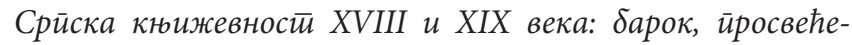

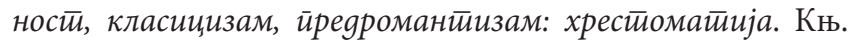
2, приредили Мило Ломпар, Зорица Несторовић, Београд: Филолошки факултет, Крагујевац: Нова Светлост.

Паз 1979: Октавио Паз, Лук и лира, Београд: Вук Караџић.

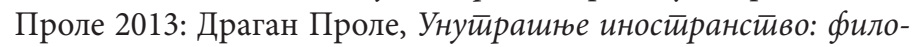
зофска рефлексија романтиизма, Издавачка књижарница Зорана Стојановића, Сремски Карловци; Нови Сад.

Радичевић 1999: Бранко Радичевић, Сабране йесме, приредио Душан Иванић, Београд: СКЗ.

Селимовић 1990: Меша Селимовић, За и ирройив Вука, Београд: БИГЗ, Сарајево: Свјетлост.

СНП 1958: Срйске нароgне иесме Београд: Просвета.

Стојановић 2011: Драган Стојановић, Феноменолоіија и вишезначносии књижевної gела, Службени гласник, Београд.

Хегел 1970: Georg Vilhelm Fridrih Hegel, Estetika, I-III, preveo dr Nikola Popović, predgovor: Dragan M. Jeremić, Beograd: Kultura. 


\section{Vojo Kovačević}

\section{VUK AND BRANKO}

The contribution of Branko Radičević's poetry to Vuk Karadžić's struggle for the introduction of the folk language and phonetic spelling is of crucial importance. Although the use of the folk language in the Serbian literary tradition is present even before the appearance of Branko Radicevic, only with his Poems1847, its flexibility, melodicity, semantic and grammatical complexity, both in relation to speech specificity and in relation to the previous oral and written literary tradition, has come to the fore. The fundamental significance of his poetry is also an artistic contribution in determining not only the lexical but also the grammatical system in the folk language. The developed grammatical system and a spelling based on the folk language will become a norm two decades after the publication of Branko's poems, and we can notice the genesis of the development of the folk language in written literature from the work of Racan, Orfelin, Jovan Rajic, Sima Milutinovic Sarajlija, Njegos including Musicki and Sterija.

Key words: Branko Radičević, poetry, folk language, Vuk St. Karadžić, reform, tradition, art. 